\section{EXERCISE, BLOOD PRESSURE AND MORTALITY: FINDINGS OF EIGHT YEARS OF FOLLOW-UP}

\author{
EXERCICIO, PRESSÃO ARTERIAL EMORTALIDADE: ACHADOS DE OITO ANOS DESEGUIMENTO
}

EJERCICIO, PRESIÓN ARTERIAL Y MORTALIDAD: HALLAZGOS DE OCHO AÑOS DE SEGUIMIENTO

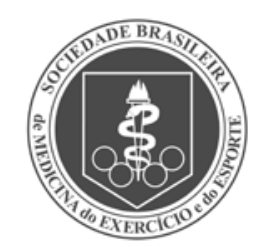

Original Article

Artigo Original

Artículo Original

\author{
Bruna Camilo Turi' \\ (Profissional de Educação Física) \\ Mariana Rotta Bonfim' \\ (Profissional de Educação Física) \\ Jamile Sanches Codogno² \\ (Profissional de Educação Física) \\ Rômulo Araújo Fernandes² \\ (Profissional de Educação Física) \\ Lia Grego Muniz de Araújo' \\ (Profissional de Educação Física) \\ Sandra Lia do Amaral ${ }^{3}$ \\ (Profissional de Educação Física) \\ Henrique Luiz Monteiro ${ }^{3}$ \\ (Profissional de Educação Física)
}

1. Universidade Estadual Paulista, Instituto de Biociências, Campus de Rio Claro, Rio Claro, SP, Brasil.

2. Universidade Estadual Paulista, Campus de Presidente Prudente, Departamento de Educação Física, Presidente Prudente, SP, Brasil.

3. Universidade Estadual Paulista, Campus de Bauru, Departamento de Educação Física, Bauru, SP, Brasil.

\section{Correspondência:}

Instituto de Biociências, Universidade Estadual Paulista, Campus de Rio Claro. Av. 24a, 1515, Rio Claro, SP, Brasil. 1306-900. brunaturi@hotmail.com

\begin{abstract}
Introduction: In the last decades, unhealthy habits, such as low levels of physical activity and poor diet, have increased. Consequently, the prevalence of cardiovascular diseases and mortality has increased significantly among adults. However, it is known that regular physical exercises help to improve health outcomes. Thus, the aim of this study was to analyze the effects of eight years of regular participation in an exercise program on blood pressure and mortality in the Brazilian public health system. Methods: The sample consisted of 34 participants with hypertension and/or type II diabetes who were followed up for eight years. They were paired by age, body mass index and chronic disease in two groups: exercise and control. During the follow-up period, medical records were used to assess systolic and diastolic blood pressure, as well as number of medical appointments and the occurrence of deaths. Results: In the follow-up period, five participants died in the control group and none in the exercise group. The Kaplan-Meier analysis identified 29.4\% lower mortality among active participants (Fisher's exact test with $p=0.044$ ). The number of medical appointments and the values of diastolic blood pressure were significantly lower for active participants. Conclusion: After a follow-up of eight years, participants in the exercise group attended fewer medical appointments, had better blood pressure control and a lower occurrence of deaths.
\end{abstract}

Keywords: mortality; hypertension; diabetes mellitus; exercise.

\section{RESUMO}

Introdução: Nas últimas décadas, hábitos pouco saudáveis, como baixos níveis de atividade física e má alimentação, têm aumentado. Consequentemente, a prevalência de doenças cardiovasculares e de mortalidade aumentou significativamente entre adultos. Entretanto, é sabido que a prática regular de exercícios físicos ajuda a melhorar os desfechos de saúde. Assim sendo, o objetivo deste estudo foi analisar os efeitos de oito anos de participação regular em um programa de exercícios sobre a pressão arterial e a mortalidade no sistema brasileiro de saúde pública. Métodos: A amostra foi composta por 34 participantes com hipertensão e/ou diabetes tipo II, que foram acompanhados por oito anos. Eles foram pareados por idade, índice de massa corporal e doença crônica em dois grupos: exercício e controle. Durante o perío do de acompanhamento, os registros médicos foram usados para avaliar a pressão arterial sistólica e diastólica, bem como o número de consultas médicas e a ocorrência de óbitos. Resultados: No período de acompanhamento, ocorreram cinco óbitos no grupo controle e nenhum no grupo exercício. A análise de Kaplan-Meier identificou mortalidade 29,4\% menor entre os participantes ativos (teste exato de Fisher com $p=0,044$ ). A quantidade de consultas médicas e pressão arterial diastólica foram significantemente menores para os participantes ativos. Conclusão: Após acompanhamento de oito anos, participantes do grupo exercício tiveram menor número de consultas médicas, melhor controle da pressão arterial e menor ocorrência de mortes.

Descritores: mortalidade; hipertensão; diabetes mellitus; exercício.

\section{RESUMEN}

Introducción: En las últimas décadas, han aumentado los hábitos poco saludables, como los bajos niveles de actividad física y la mala alimentación. Por consiguiente, la prevalencia de enfermedad cardiovascular y la mortalidad fue significativamente mayor entre los adultos. Sin embargo, se sabe que el ejercicio físico ayuda a mejorar los resultados en salud. Por lo tanto, el objetivo de este estudio fue analizar los efectos de ocho años de participación regular en un programa de ejercicios sobre la presión arterial y la mortalidad en pacientes del sistema brasileño de salud pública. Métodos: La muestra consistió en 34 participantes con hipertensión y/o diabetes tipo Il que fueron seguidos durante ocho años. Ellos fueron pareados por edad, índice de masa corporal y enfermedad crónica, en dos grupos: ejercicio y control. Durante el perío do de seguimiento, se utilizaron los registros médicos para evaluar la presión sistólica y diastólica, así como el número de consultas médicas y la ocurrencia de muertes. Resultados: En el período de seguimiento, hubo cinco muertes en el grupo control y ninguna en el grupo de ejercicio. El análisis de Kaplan-Meier identificó 29,4\% de mortalidad más baja entre los participantes activos (prueba exacta de Fisher $p=0,044$ ). El número de consultas médicas y la presión arterial diastólica fueron significativamente menores para los participantes activos. Conclusión: Después de un seguimiento de ocho años, 
los participantes en el grupo de ejercicio tuvieron un menor número de consultas médicas, un mejor control de la presión arterial y menor incidencia de muertes.

Descriptores: mortalidad; hipertensión; diabetes mellitus; ejercicio.

\section{INTRODUCTION}

During the last few decades, participation in physical activity has decreased and unhealthy dietary habits have increased. Over the same period of time, the prevalence of cardiovascular diseases and mortality has increased significantly among adults ${ }^{1}$. The development of drugs to treat these cardiovascular complications has improved both the treatment and quality of life of patients. However, non-pharmacological interventions (such as physical activity) should be the first approach to treating cardiovascular complications².

Previous studies have identified a lower prevalence of cardiovascular complications and mortality among physically active people ${ }^{3,4}$. Moreover, the practice of physical activity both increases life expectancy ${ }^{5}$ and decreases healthcare expenditures ${ }^{6,7}$. For developing nations, however, no longitudinal data exist concerning the effects of physical activity on medical consultations and mortality in patients who receive care from the public healthcare system.

The purpose of this study was to analyze the effects of eight years of regular physical exercise on blood pressure and mortality among patients of the Brazilian National Health System.

\section{METHODS}

\section{Sample}

The study covered the period from 2003 to 2010 in Bauru city ( 360,000 inhabitants), a medium-sized Brazilian city, located at middle part of Sao Paulo State, the richest state of the Brazilian federation.

In the city of Bauru, the primary care of the Brazilian National Health System is organized in 17 primary health care units (small units spread over different regions of the city, which are devoted to: medical consultations [different medical specialties], low complexity medical procedures, medicine delivery and vaccines) and this study was conducted with patients by one of them (BHU "Otávio Rasi").

The pair-matched sample of 34 patients was randomly selected to match sex, chronological age, body mass index status and chronic disease (2 paired diabetic patients; 22 paired hypertensive patients and 10 paired patients with both diseases), then assigned into exercise group ( $E G, n=17)$ and control group ( $C G, n=17)$ and followed up for eight years.

The exercise program occurred within the university and was led by undergraduate students under supervision. It consisted in 40 minutes of walking at moderate intensity (40-65\% of maximum oxygen uptake) and 20-25 minutes of strength training using dumbbells three times per week.

The study was approved by Ethics Committee of the Municipal Health Department of Bauru/SP (Document from March 22 ${ }^{\text {nd }} 2003$ ) and all participants signed the written consent form.

Patients' medical records were used to compute the dependent variables, including systolic (SBP) and diastolic (DBP) blood pressure and number of nursing and medical (e.g. dentist, gynecologist, endocrinologist, cardiologist, obstetrician, general practitioner and psychiatrist) consultations per year. The occurrence of deaths among patients was obtained through medical records and family report.

\section{Statistical analysis}

Data presented non-parametric distribution and, therefore, the Friedman test compared numerical values through follow up. Numerical variables were presented as median and interquartile range values. General characteristics at baseline were compared using the Mann-Whitnney's test. Fisher's exact test and Kaplan-Meier analysis were used to treat the categorical variables. BioEstat (release 5.0) processed all analyses, and statistical significance was set at $p<0.05$.

\section{RESULTS}

Women represented $66.5 \%$ of the sample. The average age of the sample was 70.7 years old $( \pm 10.3)$. There were no differences in baseline values between the EG and CG (Table 1). In the EG, the Friedman test identified differences in SBP $(p=0.024)$ and DBP $(p=0.001)$. Compared to baseline values, DBP in EG increased in third and fourth years of follow up, but decreased significantly in the eighth year ( $p=0.044)$. SBP did not differ from the baseline (Figure 1).

Figure 2 is a table of survival, in which the Kaplan-Meier test shows the probability of remaining alive during the follow-up. It was observed that the CG showed a reduction of $29.4 \%$ in their probability of survival over follow-up analysis. Similarly, a significant association was found between mortality and exercise practice $(p=0.044)$.

Compared to the baseline year, the number of medical consultations decreased significantly in EG (Figure 3).

\section{DISCUSSION}

This prospective study followed hypertensive and diabetic patients for eight years. Those who regularly engaged in physical exercise had decreased mortality, DBP and quantity of medical consultations.

Similar to our findings, Farrell and colleagues ${ }^{8}$ found that men who engaged in moderate and vigorous physical exercise had a lower mortality risk than sedentary men after 19 years of follow-up. Similar results have been observed among elderly ${ }^{9}$. Both our findings and current scientific

Table 1. General characteristics of the patients at baseline study (Brazil, 2003).

\begin{tabular}{c|c|c|c}
\hline \multirow{2}{*}{ Variables } & EG $(\mathbf{n}=17)$ & CG $(\mathbf{n}=17)$ & \multirow{2}{*}{$\boldsymbol{p}$} \\
\cline { 2 - 3 } & Median (IR) & Median (IR) & \\
\hline Age (years) & $66.6(61.3 / 80.1)$ & $67.3(61.2 / 79.4)$ & 0.890 \\
\hline Body weight $(\mathrm{kg})$ & $70.7(65.8 / 87.9)$ & $62.3(60.6 / 75.9)$ & 0.150 \\
\hline SBP $(\mathrm{mmHg})$ & $126.7(122.8 / 136.7)$ & $131.4(118.6 / 145.3)$ & 0.586 \\
\hline DBP $(\mathrm{mmHg})$ & $80(74.2 / 84.3)$ & $81.7(71.9 / 88.3)$ & 0.658 \\
\hline Medical consultations & $6(2 / 7)$ & $5(4.5 / 7)$ & 0.683 \\
\hline
\end{tabular}

$\mathrm{EG}=$ exercise group; $\mathrm{CG}=$ control group; $\mathrm{SBP}=$ systolic blood pressure; $\mathrm{DBP}=$ diastolic blood pressure; $\mathrm{IR}=$ interquartile range.

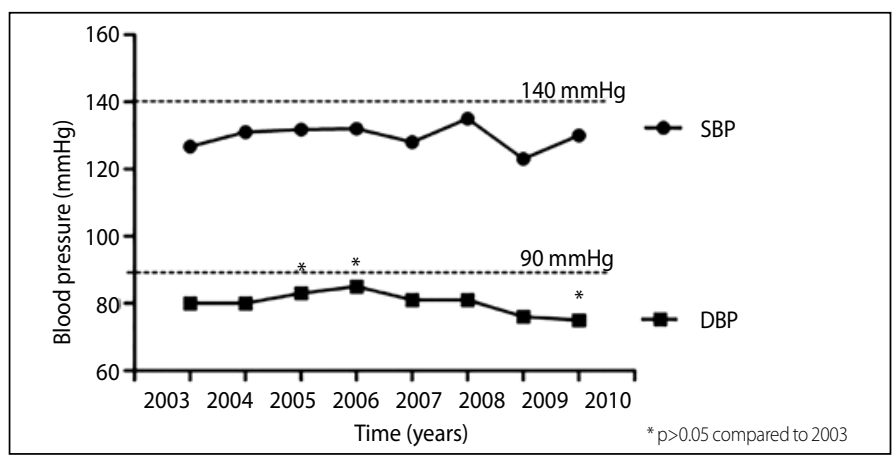

Figure 1. Blood pressure (exercise group) values during the follow up study (Brazil, 2003 - 2010). SBP= Systolic Blood Pressure; DBP= Diastolic Blood Pressure. 


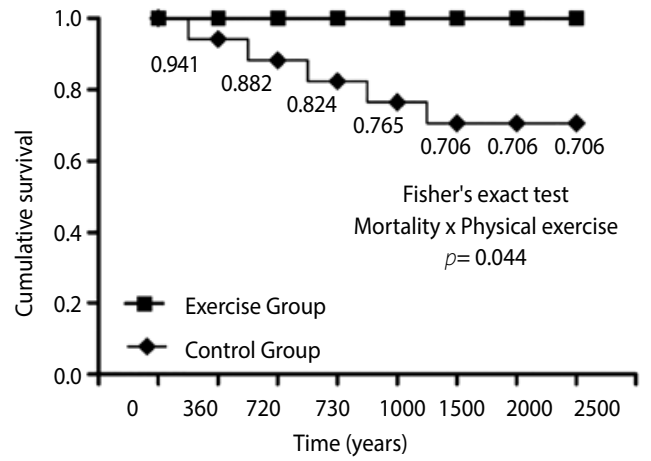

Figure 2. Kaplan-Meier survival curve for mortality according to exercise engagement (Brazil, 2003 - 2010)

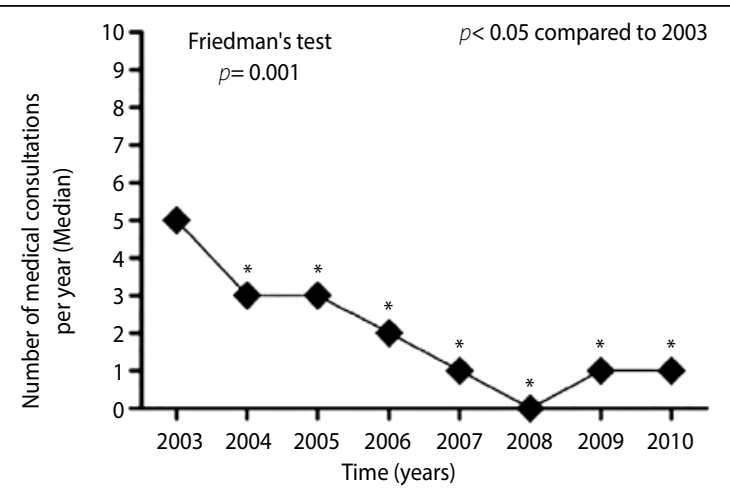

Figure 3. Number of medical consultations (exercise group) during the follow up study (Brazil, 2003 - 2010).

literature have shown that regular exercise protects against early mortality, even among elderly with chronic diseases. However, future studies are needed to identify the ideal type and amount of exercise for preventing mortality and complications associated with chronic diseases. Among adults, a physically active lifestyle has been associated with a lower incidence of arterial hypertension ${ }^{10,11}$. In a study that included 40 years of follow-up, long-term practice of physical activity had a protective effect on incidence of cardiovascular disease and all-cause and CVD-attributable mortality in men, compared with long-term physical inactivity³.

Among the hypertensive patients in the present study, blood pressure was reduced after eight years of regular exercise. A number of studies have reported that exercise reduces blood pressure in both hypertensive and normotensive subjects ${ }^{12-14}$. Although the mechanisms by which regular exercise reduces blood pressure are not completely clear ${ }^{15-17}$, the benefits of physical activity may accrue through reduction of other cardiovascular risk factors, such as improved glucose tolerance ${ }^{18}$ or lower $\mathrm{BMI}$ and visceral fat ${ }^{19}$, resulting in a lower occurrence of comorbidities associated with hypertension ${ }^{20}$. In addition, long-term regular physical activity preserves cardiac compliance ${ }^{21}$, endothelial regulation of smooth muscle tone and other aspects of vascular wall structure/function ${ }^{22}$, workload and cardiac performance ${ }^{23}$. Additionally, aerobic exercise training may significantly lower blood pressure in older hypertensive individuals, improving endothelial function and vascular tone ${ }^{24}$.

In the present study the number of medical consultations was reduced among those in the exercise group. Few studies have examined the relationship between healthcare costs and regular exercise. Recently, studies have identified reductions in expenditures related to medical consultations and the use of medicine among hypertensive ${ }^{25}$ and diabetic ${ }^{7,26}$ patients of the Brazilian National Health System, showing that people who exercise regularly are sick less often, therefore they don't go to the medical consultations as much. Also, the positive effects of regular physical activity on cognitive function, mood disorders and sleep quality, could improve the wellness of the individual ${ }^{27}$ and, therefore, improve their self-perception of health, which would reduce the number of medical consultations.

Recently, a systematic review ${ }^{28}$ evaluating the effects of physical activity on mortality in hypertensive patients between 1985 to 2012 reported that cardiovascular and / or all-cause mortality were inversely related to increased physical activity. The review noted, however, the lack of research to assess the effects of regular physical exercise on mortality and control of blood pressure in hypertensive patients over a follow-up period, which was the focus of the present study.

Some limitations of the study must be considered when interpreting the results. The small number of individuals in the sample and the fact that we did not assess confounding factors such as smoking, genetic background and other chronic diseases as heart attack, stroke and cancer that could have influenced the observed associations.

\section{CONCLUSIONS}

In summary, the longitudinal effects of regular exercise in diabetic and hypertensive patients were to reduce the number of healthcare services used and the mortality rate, in addition to better blood pressure control.

\section{ACKNOWLEDGEMENTS}

The Brazilian Federal Agency for Support and Evaluation of Graduate Education (CAPES) and Department of Health of Bauru.

All authors have declared there is not any potential conflict of interests concerning this article.

AUTHORS' CONTRIBUTIONS: Each author contributed individually and significantly to the development of the manuscript. BCT (0000-0002-1314-6258)* and MRB (0000-0002-8677-1185)* performed the data collection. RAF (0000-0003-1576-8090)*analyzed the data statistically. SLA (0000-0001-9473-3739)* and HLM (0000-0001-6639$1532)^{*}$ were responsible for the design of the study. BCT, MCB, JSC (0000-0003-4273-9375)*, RF, LGMA (0000-0002-2885-7730)*, SLA, HLM performed the interpretation of the results, actively contributed to the discussion of the results, reviewed and approved the final version of the manuscript. ${ }^{*} \mathrm{ORCID}$ (Open Researcher and Contributor ID).

\section{REFERENCES}

1. Santulli G. Epidemiology of cardiovascular disease in the 21 st century: updated numbers and updated facts. J Cardiov Dis. 2013;1 (1):1-2.]

2. Eckel RH, Jakicic JM, Ard JD, de Jesus JM, Houston Miller N, Hubbard VS, et al. 2013 AHA/ACC guideline on lifestyle management to reduce cardiovascular risk: a report of the American College of Cardiology/ American Heart Association Task Force on Practice Guidelines. J Am Coll Cardiol. 2014;63(25 Pt B):2960-84

3. Shortreed SM, Peeters A, Forbes AB. Estimating the effect of long-term physical activity on cardiovascular disease and mortality: evidence from the Framingham Heart Study. Heart. 2013;99(9):649-54

4. Reddigan II, Ardern Cl, Riddell MC, Kuk JL. Relation of physical activity to cardiovascular disease mortality and the influence of cardiometabolic risk factors. Am J Cardiol. 2011;108(10):1426-31.

5. Wen CP, Wai JP, Tsai MK, Yang YC, Cheng TY, Lee MC, et al. Minimum amount of physical activity for reduced mortality and extended life expectancy: a prospective cohort study. Lancet. 2011;378(9798):1244-53.

6. Alter DA, Wijeysundera HC, Franklin B, Austin PC, Chong A, Oh Pl, et al. Obesity, lifestyle risk-factors, and health service outcomes among healthy middle-aged adults in Canada. BMC Health Serv Res. 2012;12:238

7. Codogno JS, Fernandes RA, Sarti FM, Freitas Júnior IF, Monteiro HL. The burden of physical activity on type 2 diabetes public healthcare expenditures among adults: a retrospective study. BMC Public Health. 2011;11:275

8. Farrell SW, Finley CE, Radford NB, Haskell WL. Cardiorespiratory fitness, body mass index, and heart failure mortality in men: Cooper Center Longitudinal Study. Circ Heart Fail. 2013;6(5):898-905.

9. Ueshima K, Ishikawa-Takata K, Yorifuji T, Suzuki E, Kashima S, Takao S, et al. Physical activity and mortality risk in the Japanese elderly: a cohort study. Am J Prev Med. 2010;38(4):410-8. 
10. Jae SY, Heffernan KS, Yoon ES, Park SH, Carnethon MR, Fernhall B, et al. Temporal changes in cardiorespiratory fitness and the incidence of hypertension in initially normotensive subjects. Am J Hum Biol. 2012;24(6):763-7.

11. Lee DC, Sui X, Church TS, Lavie CJ, Jackson AS, Blair SN. Changes in fitness and fatness on the development of cardiovascular disease risk factors hypertension, metabolic syndrome, and hypercholesterolemia. J Am Coll Cardiol. 2012;59(7):665-72.

12. Sikiru L, Okoye GC. Effect of interval training programme on pulse pressure in the management of hypertension: a randomized controlled trial. Afr Health Sci. 2013;13(3):571-8.

13. Cornelissen VA, Smart NA. Exercise training for blood pressure: a systematic review and meta-analysis. J Am Heart Assoc. 2013;2(1):e004473.

14. Huang G, Shi X, Gibson CA, Huang SC, Coudret NA, EhIman MC. Controlled aerobic exercise training reduces resting blood pressure in sedentary older adults. Blood Press. 2013;22(6):386-94.

15. Moraes-Silva IC, Mostarda C, Moreira ED, Silva KA, dos Santos F, de Angelis K, et al. Preventive role of exercise training in autonomic, hemodynamic, and metabolic parameters in rats under high risk of metabolic syndrome development. J Appl Physiol (1985). 2013;114(6):786-91.

16. Araujo AJ, Santos AC, Souza Kdos S, Aires MB, Santana-Filho VJ, Fioretto ET, et al. Resistance training controls arterial blood pressure in rats with L-NAME- induced hypertension. Arq Bras Cardiol. 2013;100(4):339-46.

17. Brown MD, Feairheller DL. Are there race-dependent endothelial cell responses to exercise? Exerc Sport Sci Rev. 2013;41(1):44-54

18. Herzig KH, Ahola R, Leppäluoto J, Jokelainen J, Jämsä T, Keinänen-Kiukaanniemi S. Light physical activity determined by a motion sensor decreases insulin resistance, improves lipid homeostasis and reduces visceral fat in high-risk subjects: PreDiabEx study RCT. Int J Obes (Lond). 2014;38(8):1089-96.
19. Larsen BA, Allison MA, Kang E, Saad S, Laughlin GA, Araneta MR, et al. Associations of physical activity and sedentary behavior with regional fat deposition. Med Sci Sports Exerc. 2014;46(3):520-8.

20. Long AN, Dagogo-Jack S. Comorbidities of diabetes and hypertension: mechanisms and approach to target organ protection. J Clin Hypertens (Greenwich). 2011;13(4):244-51.

21. Prasad A, Popovic ZB, Arbab-Zadeh A, Fu Q, Palmer D, Dijk E, et al. The effects of aging and physical activity on Doppler measures of diastolic function. Am J Cardiol. 2007;99(12):1629-36.

22. Costanzo P, Perrone-Filardi P, Vassallo E, Paolillo S, Cesarano P, Brevetti G, et al. Does carotid intima-media thickness regression predict reduction of cardiovascular events? A meta-analysis of 41 randomized trials. J Am Coll Cardiol. 2010;56(24):2006-20.

23. Belardinelli R, Georgiou D, Cianci G, Purcaro A. 10-year exercise training in chronic heart failure: a randomized controlled trial. J Am Coll Cardiol. 2012;60(16):1521-8.

24. Dengel DR, Brown MD, Reynolds TH, Kuskowski MA, Supiano MA. Effect of aerobic exercise training on blood pressure sensitivity to dietary sodium in older hypertensives. J Hum Hypertens. 2006;20(5):372-8.

25. Rolim LMC, Amaral SL, Monteiro HL. Hipertensão e exercício: custos do tratamento ambulatorial, antes e após a adoção da prática regular e orientada de condicionamento físico. Hipertensão. 2007;10(2):55-62

26. Codogno JS, Fernandes RA, Monteiro HL. Physical activity and healthcare cost of type 2 diabetic patients seen at basic units of healthcare. Arq Bras Endocrinol Metabol. 2012;56(1):6-11.

27. Mello MT, Boscolo RA, Esteves AM, Tufik S. O exercício físico e os aspectos psicobiológicos. Rev Bras Med Esporte. 2005;11(3):203-7.

28. Rossi A, Dikareva A, Bacon SL, Daskalopoulou SS. The impact of physical activity on mortality in patients with high blood pressure: a systematic review. J Hypertens. 2012;30(7):1277-88. 